\title{
Kronik Böbrek Hastalığında Renal İnflamasyon ve Bazı Güncel Diyet Bileşenleri İlişkisi
}

\author{
Relationship Between Renal Inflammation and \\ Some Current Dietary Components in Chronic Kidney Disease
}

\section{ÖZ}

Kronik böbrek hastalığı, glomerüler filtrasyonun azalmasıyla böbrekte sıv1-solüt dengesinin düzenlenmesi ve metabolik-endokrin fonksiyonlarda kronik ve ilerleyici bozulma hali olarak tanımlanabilir. Kronik böbrek hastalığı gelişiminde rol alan inflamasyon, kronik böbrek hastalığının sonucu olarak da ortaya çıkabilmekte ve KBH varlığına bağlı mortalite artışının en önemli nedenlerinden biri olarak kabul edilmektedir. İnflamasyon ve diyet etkileşimi ile ilgili yapılan güncel araştırmalar çoklu doymamış yağ asitleri, D vitamini, E vitamini gibi besin ögeleri ile karnitin, lipoik asit, flavanoidler, probiyotikler ve prebiyotikler gibi diğer diyet bileşenlerinin renal inflamasyon sürecindeki olumlu etkilerine işaret etmektedir. Derlemede, olası anti-inflamatuvar bazı diyet bileşenlerinin kronik böbrek hastalı̆̆ı ile ilişkili inflamasyon üzerine etkileri incelenmiştir.

ANAHTAR SÖZCÜKLER: Kronik böbrek hastalığı, Beslenme, İnflamasyon, Diyet

\begin{abstract}
Chronic kidney disease can be defined as chronic and progressive deterioration of the regulation of fluid-solute balance and metabolic-endocrine functions of the kidney due to diminishing glomerular filtration. Inflammation in renal disease can develop as a cause or an outcome, and it has been reported in recent studies that inflammation is among the most important causes of disease-related mortality. Investigations on inflammation and diet interactions have shown that the effects of nutrients such as polyunsaturated fatty acids, vitamin $\mathrm{D}$, vitamin $\mathrm{E}$ and other dietary components such as carnitine, lipoic acid, flavanoids, probiotics and prebiotics may have positive effects on the renal inflammation process. In this review, the potential anti-inflammatory effects of some current dietary components in chronic kidney disease were studied.
\end{abstract}

KEY WORDS: Chronic kidney disease, Nutrition, Inflammation, Diet

\section{GİRIŞ}

Kronik böbrek hastalığı $(\mathrm{KBH})$ tahmini prevalansı \% 11,0-13,0 olan global bir sağlık sorunudur (1). Türkiye'de yapılan Türkiye Kronik Böbrek Hastalıkları (Chronic Renal Disease in Turkey, CREDIT) çalışması sonuçlarına göre, 2008 yılında genel yetişkin nüfusta $\mathrm{KBH}$ prevalansı \%15,7 olarak saptanmıştır (2). Cinsiyetler arasında renal fonksiyondaki düşüşü değerlendiren prospektif çalışmalar olmamasına karşın, deneysel modellerde erkek hayvanların daha kötü renal hastalık prognozu geliştirdikleri gösterilmiştir (3). Buna karşın CREDIT çalışması sonuçlarına göre Türkiye'de KBH sıklığının kadınlarda daha fazla $(\% 55,7)$ olduğu da rapor edilmiş̧tir (2).

Kronik böbrek hastalığ 1 doğrudan veya kardiyovasküler hastalıklar (KVH) gibi diğer kronik hastalıklara bağlı olarak yüksek mortalite oranlarına sahiptir ve sağlık sistemleri açısından ekonomik yük oluşturmaktadır (4). Küresel ölüm nedenleri arasında KBH, 1990 yılında 27. sıradayken, 2010 yılında 18. sıraya yükselmiştir (5). Özellikle son evre böbrek yetmezliği olan hastalarda KVH'ya bağlı mortalite, normal popülasyona oranla 500 kata kadar daha yüksektir (6).

\author{
Neslihan ÜLGER ÖZTÜRK ${ }^{1}$ \\ Reyhan NERGIZ-UNAL ${ }^{2}$
}

1 İzmir Katip Çelebi Üniversitesi, Beslenme ve Diyetetik Bölümü, İzmir, Türkiye

2 Hacettepe Üniversitesi, Beslenme ve Diyetetik Bölümü, Ankara, Türkiye 
Kronik böbrek hastalığına bağlı morbidite ve mortalitenin en önemli nedenlerinden birinin uzun süreli düşük seviye inflamasyon olduğu düşünülmektedir. Özellikle diyaliz tedavisi alan son evre böbrek yetmezliği hastalarında pro-inflamatuvar ve anti-inflamatuvar sitokinlerin sistemik dolaşımdaki düzeylerinin; azalmış böbrek klirensi ve dejenerasyona uğrayan hücrelerin onarımına bağlı olarak çok yükseldiği bildirilmiştir (7-9).

Kronik böbrek hastalığında, hem hastalığın ilerlemesini yavaşlatmak hem de hastalığa bağlı mortaliteyi azaltmak amacıyla inflamasyonu kontrol altına almak oldukça önemlidir. Beslenmenin inflamatuvar yanıt üzerine etkilerinin olduğu aşikârdır. Ancak özellikle güncel literatürde çoklu doymamış yağ asitleri (PUFA), D vitamini, E vitamini, karnitin, lipoik asit, flavanoidler, probiyotikler ve prebiyotikler ile inflamasyon ilişkisini inceleyen birçok çalışma bulunmaktadır. Spesifik olarak bu besin ögeleri ve diyet bileşenlerinin $\mathrm{KBH}$ sürecinde inflamasyondaki rolü güncel olmasına karşın tam olarak bilinmediği için, bu bileşenler ile ilgili literatürün değerlendirilmesi amacıyla bu derleme yazı hazırlanmıştır.

\section{KRONIK BÖBREK HASTALIĞI}

Böbrek, metabolizma atıklarının atılması, vücutta su, tuz ve asit dengesinin sağlanması, çeşitli hormon ve prostoglandinlerin sentez ve salınması gibi birçok fonksiyonu olan karmaşık yapıda bir organdır. Böbrek hastalıkları da böbreğin yapısı kadar karmaşıktır, ancak bu hastalıkların incelenmesi etkilemiş olduğu dört bileşene ayrılarak kolaylaştırılmıştır. Bunlar; glomerüler, tübüler, interstisyel alan ve vasküler yapılardır (10). Kronik böbrek hastalığ ${ }_{1}$, herhangi bir böbrek hastalığ tipinin ilerleyici glomerüler, tübüler ve interstisyel hasarı sonucu kötüleşmiş ve geri dönüşü olmayan bozulmuş renal fonksiyon ile sonuçlanmaktadır (11).

Kronik böbrek hastalığının tanımlanması, sınıflandırılması ve değerlendirilmesi için 2002 yılında Amerika'da Ulusal Böbrek Derneği - Böbrek Hastalığı Sonuçları Kalite İnisiyatifi (National Kidney Foundation - Kidney Disease Outcomes Quality Initiative, K/DOQI) tarafından bir rehber yayınlamıştır (12). Daha sonra 2012 yılında bu rehber Böbrek Hastalıklarının İyileştirilmesi Dünya Sonuçları (Kidney Disease Improving Global Outcomes, KDIGO) olarak güncellenmiştir (13). Kronik böbrek hastalığı, böbreğin yapısını ve işlevini etkileyen heterojen hastalıklar için kullanılan genel bir terimdir. Raporda KBH'nin tanımı, klinik tanı olmaksızın, 3 ay veya daha uzun süredir böbrek hasarının varlığı (albuminüri) veya azalmış böbrek fonksiyonu (Glomerüler filtrasyon hızı (GFH) $<60 \mathrm{ml} /$ dakika/ $1.73 \mathrm{~m}^{2}$ ) olarak verilmiştir. İdrar albümin atım oranının $30 \mathrm{mg} / \mathrm{g}$ 'dan fazla olması ve GFH'nin $60 \mathrm{ml} /$ dakika/1.73 ${ }^{2}$ 'den düşük olması KBH'nin tanılanmasında iki önemli belirteçdir. Amerika Birleşik Devletleri Ulusal Böbrek Derneği'nin KBH için hazırladığı klinik uygulama kılavuzuna göre, KBH, GFH'na bağlı olarak beş evrede sınıflandırılmaktadır (Tablo 1) $(12,13)$. Albuminüri, GFH'den bağımsız ancak onu tamamlayıcı bir faktör olarak KDIGO'nun yeni KBH sinıflamasında yer almaktadır.

Kronik böbrek hastalığında; artmış kan basıncı, düşük eritropoietin sentezi, metabolik asidozis gelişimi ve yüksek düzeyde metabolik son ürünlerin (üremik toksinler) birikimi gözlenmektedir. $\mathrm{Bu}$ koşullar altında 'üremik durum' oluşmaktadır (6,11). Kan üre azotu (BUN) ve kreatinin seviyerinin yükselmesi ve genellikle azalmış GFH'ye eşlik eden klinik bulgular ve sistemik biyokimyasal anormallikler üremi olarak tanımlanmaktadır. Üremi yalnızca böbreğin boşaltım fonksiyonunda yetmezlik ile karakterize olmayıp böbreği zedeleyen metabolik ve endokrin değişiklikler de olaya eşlik etmektedir. Sonuçta hasarın primer yerinden bağımsız olarak glomerüler, tübüler, interstisyel, damar sklerozu ve son evre böbrek yetmezliği ile sonuçlanmaktadır (10). Bu durum diyaliz ya da transplantasyonla tedavi edilmezse üremi nedeniyle ölümle sonuçlanabilmektedir. Hemodiyaliz, peritoneal diyaliz veya böbrek transplantasyonu formunda renal replasman tedavisi gerektiren hastaların sayısı her yıl \%10-15 civarında artmaktadir (6).

Hemodiyaliz veya peritoneal diyalize başlanması için KDIGO'nun önerisi aşağıdakilerden biri veya daha fazlasının mevcut olmasıdır: Böbrek yetmezliği ile ilişkilendirilen semptomlar veya işaretler, hacim durumunu veya kan basıncını kontrol edememe, diyet müdahalesine dirençli, beslenme durumundaki ilerleyici bozulma veya bilişsel bozukluk. Bu, genellikle GFH'nın 5-10 $\mathrm{ml} / \mathrm{dak} / 1.73 \mathrm{~m}^{2}$ arasında olduğu durumlarda gözlenmektedir (13).

Dünyada KBH'nın başlıca nedenleri arasında genetik yatkınlık, etnik köken ve artan yaş gibi değiştirilemeyen faktörlerin yanı sıra; diyabet, hipertansiyon ve glomerülonefrit gibi hastalıklar sayılmaktadır $(11,14)$. Türkiye'de yapılan CREDIT çalışması sonuçlarına göre de hipertansiyon ve tip II diyabetes mellitus tanısı olan bireylerde $\mathrm{KBH}$ prevalansı daha fazla bulunmuştur (2). Tip 1 Diyabetli hastaların \%20-40 inda, Tip 2 Diyabetli hastaların \%10-20 sinde diyabete bağlı KBH gelişebilmektedir. Mikroalbuminüri ve proteinüri gelişmişse, glisemik kontrolü sağlamak ve hipertansiyonu erken tedavi etmek, KBH gelişimini yavaşlatacak en önemli girişimlerdir.

Tablo I: Kronik böbrek hastalı̆̆ı evreleri

\begin{tabular}{|c|c|c|}
\hline Evre & Tanım & GFR (mL/min $\mathbf{1 . 7 3} \mathbf{~ m}^{\mathbf{2}}$ \\
\hline 1 & $\begin{array}{c}\text { Normal veya } \uparrow \text { GFH ile } \\
\text { birlikte böbrek hasarı }\end{array}$ & $\geq 90$ \\
\hline 2 & $\begin{array}{c}\text { Hafif azalmış GFH ile } \\
\text { birlikte böbrek hasarı }\end{array}$ & $60-89$ \\
\hline 3 & Orta derecede GFH azalması & $30-59$ \\
\hline 4 & A ğır derecede GFH azalması & $15-29$ \\
\hline 5 & Böbrek yetmezliği & $<15$ (veya diyaliz) \\
\hline
\end{tabular}


Kronik böbrek hastalığı olan bireylerde hipertansiyon gelişmesi beklenen bir durumdur, ancak hipertansiyon aynı zamanda $\mathrm{KBH}$ gelişimine de neden olabilmektedir. Glomerülonefrit, glomerüllerde hasar ve inflamasyona neden olan, primer veya sekonder olarak gelişebilen klinik tablodur (15). Bunun yanı sıra $\mathrm{KVH}$, obezite ve yüksek kolesterol de $\mathrm{KBH}$ için risk faktörleridir. Ancak KBH de KVH gelişimini tetiklemektedir ve $\mathrm{KVH}$ riski hastalığın ilerlemesiyle katlanarak artmaktadır (6).

Kronik böbrek hastalığına bağlı artan morbidite ve mortalitenin en önemli nedenlerinden birinin kronik inflamasyon olabileceği düşünülmektedir (16). Özellikle son evre böbrek yetmezliğinde olmak üzere KBH'de, pro-inflamatuvar ve antiinflamatuvarsitokinlerinsistemikdolaşımdakikonsantrasyonları, azalmış böbrek klirensi gibi nedenlere bağlı olarak çok yükselmektedir. $\mathrm{Bu}$ nedenle, KBH'nin ileri evrelerinde dünya genelinde akut faz proteini olan C-reaktif protein (CRP) ölçümü ile inflamasyon durumu değerlendirilmektedir. Amerika Ulusal Sağlık ve Beslenme Araştırması (National Health and Nutrition Examination Survey III, NHANES III) raporuna göre, GFH düzeyi 15-60 mL/dak olan hastaların yarısının CRP düzeyi > 2.1 $\mathrm{mg} / \mathrm{L}$ olduğu belirtilmiştir (17). Diyaliz hastalarının medyan CRP düzeyi Avrupa'da 5 mg/L'dir. Buna karşın Amerikalıların CRP düzeyi bu değerden daha yüksek, Asyalılarınki ise daha düşüktür (18). Sonuç olarak inflamasyon ve KBH ilişkisi genetik predispozisyon etkisinde olsa da inflamasyon $\mathrm{KBH}$ için hem hastalık nedeni hem de hastalı̆̆ın progresyonu ve sonucunda oluşarak vücutta multi organ dejenerasyonlarına neden olabilmektedir (19).

\section{KRONIKK BÖBREK HASTALIĞINDA İNFLAMASYON}

İflamatuar mekanizmalar, immün sistemin hümoral ve hücresel komponentlerinin katıldı $\breve{g}_{1}$ kompleks bir süreçtir. Vücutta; patojenik mikroorganizmalar, diğer antijenler, yabancı maddeler veya böbrekte doku hasarı olduğunda koruyucu bir cevap olarak inflamatuvar (yangı) yanıt oluşturulur $(20,21)$. Akut inflamatuvar yanıt böbrekte hücre ve dokuları hasardan korumak ve iyileşmeyi başlatmak için gerekli olup, oluşan pro-inflamatuvar yanıt anti-inflamatuvar yanıt ile düzenlenmektedir. Bu nedenle, vücudun inflamatuvar yanıtının dış ve iç uyaranlara karşı dengede olması önemlidir $(21,22)$. Akut inflamasyonu başlatan ve sürdüren medyatörler (aracılar) histamin, eikosanoidler, kompleman sistem, sitokinler, kinin gibi prokoagülanlar ve fibrinolitik moleküllerdir. Kronik inflamasyonda ise akut inflamatuvar yanıt, sürecin baskılanması gerçekleşmediği veya geciktiği için dokuda pro-inflamatuvar medyatörlerin (İnterlökin-1 (IL-1), İnterlökin-6 (IL-6), Tümör nekroz faktör alfa (TNF $\alpha)$ ) birikimine ve doku hasarına neden olmaktadır. Dokuda hasar meydana gelse dahi inflamatuvar süreç devam edebilmektedir. Doku onarımı için, interlökin-4 (IL-4), interlökin-10 (IL-10), transforming büyüme faktörü beta (TGF- $\beta$ ), lipoksinler ve lökotrienler gibi pro-inflamatuvar sitokin inhibitörleri gibi çeşitli medyatörler devreye girebilmektedirler (20,23-25).
İnflamasyonun rekürrensi veya düşük dereceli uzun süreli kronik inflamasyon, $\mathrm{KBH}$ hastalarında ateroskleroz, $\mathrm{KVH}$, kaşeksi ve anemi gibi komorbiditelerin gelişiminde rol oynayabilmektedir $(26,27)$. Kronik böbrek hastalığı ile ilişkili inflamasyon; monositler, makrofajlar, granülositler ve diğer hücreler ile düzenlenen doğal immün sistemin aktivasyonuyla ilişkilidir. Monositlerin genişlemesi ve bazal integrinlerinin kısalması, toll benzeri reseptör-2 (TLR-2) ve toll benzeri reseptör-4(TLR-4) ekspresyonu; sitokin üretimi ve reaktif oksijen bileşikleri (ROS) üretimi; T regülatör (Treg) hücrelerin azalması ve inhibitör aktivitelerinin kötüleşmesi; polimorfonükleer lökosit aktivasyonu; kemokin ekspresyonu; düşük dansiteli lipoproteinin (LDL) pro-inflamatuvar aktivitesinin artması ve yüksek dansiteli lipoproteinin (HDL) anti-inflamatuvar kapasitesinin azalması; nükleer faktör eritroid 2 - ilişkili faktör 2 (Nrf2) gibi antioksidan ve sitoprotektif enzimler ve ilişkili proteinlerin genlerini kodlayan ana regülatörler ile özellikle üremik toksinler KBH'de oluşan inflamasyonun önemli bileşenleridir $(19,28,29)$.

Kronik böbrek hastalığında böbrek fonksiyonuyla inflamatuvar belirteçler arasında negatif bir ilişki bulunduğunu gösteren çalışmalar literatürde yayınlanmıştır (30-33). Yaklaşık 5000 hemodiyaliz hastası ile yapılmış bir çalışmada CRP düzeyi ile mortalite pozitif olarak ilişkili bulunmuştur. $\mathrm{Bu}$ nedenle CRP'nin özellikle hemodiyaliz tedavisi alan hastalarda takip edilmesi gereken standart bir biyokimyasal parametre olması gerektiği öne sürülmüştür (34). Son evre böbrek yetmezliği olan hastalarda IL-6'nın mortalite ve KVH'nın tahmin edilmesinde en önemli inflamatuvar belirteç olduğu gösterilmiştir (35). Diğer yandan günlük diyette yer alan bileşenlerin inflamasyonun belirlenmesinde temel bir rolü bulunduğu son 10 yıldır araştırılan güncel bir konudur. Onlarca besin ögesi ve diyet bileşeni ile hesaplanan diyetin inflamatuvar indeksi skoru artı yöne doğru arttıkça inflamasyon durumunun azaldığı bildirilmiştir $(36,37)$.

\section{KRONIK BÖBREK HASTALIĞI SÜRECINDE İNFLAMASYON ve GÜNCEL DIYYET BILLEŞENLERİ}

\section{Çoklu Doymamış Yağ Asitleri}

Yağ asitlerinin immün sistemde görevleri; immün sistem hücreleri için enerji kaynağı, fosfolipidlerin yapısal komponenti ve membran yapısı ve fonksiyonları için elzem olmalarıdır. Çoklu doymamış yağ asitleri (PUFA) ayrıca gen ekspresyonu ve sinyal yolaklarını düzenler, eikosanoidlerin ve diğer lipid yapılı aracı maddelerin öncüsüdürler $(38,39)$.

Alfa-linolenik asit (ALA 18:3 n-3 PUFA), eikozapentaenoik asit (EPA 20:5 n-3 PUFA), dokozahekzaenoik asit (DHA 22:6, n-3 PUFA) ve linoleik asit (LA 18:2, n-6 PUFA) çoklu doymamış yağ asitleridir. Uzun zincirli elzem n-3 PUFA ve n-6 PUFA sınıfları lipoksigenaz ve siklooksigenaz enzimleri için substrat olup böylece hormon benzeri eikozanoidlerin sentezinde görev almaktadır (40). N-3 ve n-6 yağ asitlerinin, immün sistemi etkileyebilmesi için uzun zincirli ya $\breve{g}$ asitlerine dönüştürülmesi 
gerekmektedir (41). Bunlar; n-6 yağ asitlerinden arakidonik asit (AA, 20:4); n-3 yă asitlerinden ise EPA ve DHA'dır. Bu yağ asitleri immün sistem hücrelerinin membranına yerleştikten sonra prostaglandin, lökotrien ve tromboksan gruplarını içeren hormon benzeri etkilere sahip olan ara ürünlere yani eikozanoidlere dönüştürülebilmektedir. Diyetteki özellikle n-3 PUFA türüne göre immün sistem hücreleri farklı tür ve miktarlarda eikozanoid üreterek farklı immün yanıta neden olabilmektedir. Pro-inflamatuvar süreçte daha çok n-6 yă asitleri etkili iken, n-3 yağ asitleri daha çok anti-inflamatuvar yanitta etkindirler (42).

Kronik böbrek hastalarının diyet PUFA alımları genellikle yetersiz olmasına karşın, PUFA suplemantasyonunun olumlu rolü olabileceği düşünülmektedir (22). Avustralya'da yapılan epidemiyolojik bir araştırmada, bireylerin diyet PUFA (n-3, n-6 ve $\alpha$-linolenik asit) ve balık tüketimi ile $\mathrm{KBH}$ prevalans1 değerlendirilmiştir. Buna göre; n-3 yağ asitleri ve balık tüketimi fazla olanlarda orta derece (en az 3. evre) $\mathrm{KBH}$ riskinin anlamlı oranda daha düşük olduğu rapor edilmiştir (43). İtalya'da yapılan ve 65 yaş ve üstü bireylerin dahil edildiği diğer bir epidemiyolojik prospektif çalışmada, n-3 ve n-6 PUFA tüketiminin böbrek fonksiyonlarındaki yaşa bağlı düşüşü yavaşlatabileceği gösterilmiştir (44). Diğer yandan in vitro çalışmalarda n-3 PUFA'nın, TGF- $\beta$ yolaklarının modülasyonu ve hücre büyüme faktörlerinin regülasyonuyla renal fibrozis düzeylerinin düşürülebildiği bildirilmiştir $(45,46)$. İnflamatuar sürecin modifikasyonu için çeşitli koşullarda bu bileşiklerin suplementasyonu üzerine araştırmalar yapılmaktadır. KBH kohortlarını içeren çalışmalar kısıtlıdır, ancak mevcut çalışmalarda özellikle de diyaliz tedavisi alan veya böbrek transplantasyonu yapılmış son evre böbrek yetmezliği hastalarında, PUFA suplementasyonunun CRP ile ölçülen inflamasyonu azaltabildiği ve IL-6 ve TNF- $\alpha$ düzeylerinde düşüş ile sonuçlanabileceği gösterilmiştir. $\mathrm{Bu}$ nedenle, böbrek hasarı açısından risk altında olan, özellikle de yaşı bireylerde, n-3 ya $\breve{g}$ asitlerinden zengin bir diyet tüketiminin koruyucu olabileceği düşünülmektedir $(22,47,48)$.

Çoklu doymamış omega-3 yani n-3 yă̆ asitleri (EPA ve DHA) suplemantasyonunun, ilerleyici renal fibroziste böbrek fonksiyonunu ve yapısını iyileştirdiği gösterilmiştir. Yapılan bir çalışmada ratlarda balık yağı suplemantasyonunun, makrofaj infiltrasyonunu, TGF- $\beta$ ekspresyonunu, apoptozisi ve arakidonik asit, IL-1 $\beta$, monosit kemoatraktan protein 1 (MCP1) ve lökotrien B4'ün (LTB4) dokuda seviyelerini azaltarak, obstrüktif böbrek hasarının patofizyolojisini zayıflattığı gösterilmiştir (49).

Hemodiyaliz tedavisi alan son evre böbrek yetmezliği hastalarında sıklıkla insülin direnci gelişebilmektedir. Yapılan bir çalışmada, hemodiyaliz tedavisi alan son evre böbrek yetmezliği hastalarında, 8 hafta boyunca günde $2.4 \mathrm{~g}$ EPA+DHA suplemantasyonu yapılmış ve sonuç olarak hastalarda insülin direncinin azaldığı ve yüksek duyarlı CRP (hs-CRP), TNF- $\alpha$ ve
IL-6 gibi inflamatuvar parametrelerin anlamlı oranda düştüğü gösterilmiştir (47). Başka bir çalışmada hemodiyaliz tedavisi alan son evre böbrek yetmezliği hastalarında 2 ay süresince $2.4 \mathrm{~g} /$ gün n-3 yağ asitleri suplemantasyonu yapılmış ve tedavi sonucunda EPA düzeyinin anlamlı oranda yükseldiği ve IL-6 ve TNF- $\alpha$ düzeylerinin anlamlı oranda düştüğü gösterilmiştir (50). Son evre böbrek yetmezliği olan ve sürekli ayaktan periton diyalizi (SAPD) tedavisi alan hastalara 8 hafta boyunca günde 3 defa olmak üzere n-3 suplemantasyonu (her kapsülde 180 mg EPA ve 120 mg DHA) yapılmış ve plasebo alan kontrol grubuyla karşılaştırılmıştır. Bu çalışmada SAPD tedavisi alan hastalarda, n-3 suplemantasyonunun serum IL-6 ve kantitatif CRP düzeylerini anlamlı oranda düşürdüğü saptanmıştır (51).

Böbrek transplantasyonu yapılan bireylerde n-3 PUFA suplementasyonuyla sistemik inflamasyonun düşürülebileceği ve renal ve kardiyovasküler prognozun iyileştirilebileceği düşünülmektedir. Bu konuda yapılan bir çalışmada 6 ay süresince n-3 PUFA'dan zengin (6. ayın sonunda n-3 alımı $2.6 \pm$ $0.93 \mathrm{~g} /$ gün) diyet alan böbrek transplantasyonu geçiren son evre böbrek yetmezliği hastalarında kontrol grubuna göre hs-CRP ve IL-6 düzeylerinin düştügü saptanmıştır (48).

Çoklu doymamış n-3 yă as atlerinin anti-inflamatuvar etkilerine dair mekanizmalar net olmamasına karşın yalnızca CRP düzeylerinin değil ayrıca peroksizom proliferatör aktive reseptörlerin (PPAR) özellikle de peroksizom proliferatör aktive reseptör gammanın (PPAR $\gamma$ ) pro-inflamatuvar sitokinleri inhibe ettiği gösterilmiştir. Bu konuda yapılan in vitro bir çalışmada böbrek hücresinde, EPA ve DHA'nın, PPAR $\gamma$ bağımlı bir yolak üzerinden, nükleer faktör kappa $b(\mathrm{NF}-\varkappa \mathrm{B})$ aktivasyonunu ve MCP-1 ekspresyonunu anlamlı şekilde azalttı̆̆ gösterilmiştir (52).

\section{Vitamini}

İnsan vücudunda ultraviyole ışınların etkisiyle provitamin D vitamininden aktif D vitamini endojen olarak sentezlenmektedir. Derideki kolekalsiferolden karaciğerde 25-hidroksivitamin D (25(OHD)) ve sonra ikinci hidroksilasyon böbrekte gerçekleşerek 25(OHD)'den 1,25-dihidroksivitamin D $\left(1,25(\mathrm{OH})_{2} \mathrm{D}\right)$ yani kalsitriol sentezlenmektedir (53).

Kronik böbrek hastalığ1 olan bireylerde $1,25(\mathrm{OH})_{2} \mathrm{D}$ düzeylerinin düşmesinin birçok nedeni olmasına karşın en önemlisi böbrek kütlesinin azalmasına bağlı olarak 1- $\alpha$-hidroksilaz düzeylerinin yavaş yavaş ve kademeli olarak azalmasıdır. Böbrekte D vitamininin hidroksillenerek aktif forma dönüşmesini engelleyen etmenler arasında hiperparatiroidizm ve hiperfosforemi de bulunmaktadır. Kötüleşen böbrek fonksiyonları ve $1 \alpha$-hidroksilaz eksikliğine bağlı olarak, ileri evre ve son evre böbrek hastalarında genellikle $25(\mathrm{OH}) \mathrm{D}$ ve $1,25(\mathrm{OH})_{2} \mathrm{D}$ eksikliği gözlenmektedir $(16,53)$.

Kronik böbrek hastalığ 1 olan bireyler, $25(\mathrm{OH}) \mathrm{D}$ yetersizliği açısından yüksek risk altındadırlar çünkü $1,25(\mathrm{OH})_{2} \mathrm{D}$ düzeylerinin regülasyonunu sağlayamamaktadırlar. Son evre 
böbrek yetmezliğinde diyalizin başlamasıyla birlikte, böbrek hastalarının dramatik bir şekilde artmış erken ölüm riski ile karşı karşıya kalabildikleri bildirilmiştir. Diyaliz hastalarında düşük D vitamini düzeyleri artmış mortalite ile ilişkilendirilmektedir (54).

D vitamininin anti-inflamatuvar etkilerinin altında yatan mekanizmaları incelendiğinde, inflamasyon açısından D vitamininin makrofajlar, dendritik hücreler ve $\mathrm{T}$ hücreleri üzerine etkisi böbrek fonksiyonunun ilerleyici kaybında önemlidir $(55,56)$. D vitamini suplementasyonu ile TNF- $\alpha$ ve NF- $x \beta$ yolakları modifiye edilerek inflamatuvar yolakta makrofajlar modüle edilebilmektedir (22). Erken dönem kronik böbrek hastaları (evre 2 ve 3 ) ile yapılan randomize kontrollü bir çalışmada, bireylere 12 hafta boyunca haftada bir defa ve takip eden 40 hafta süresince iki haftada bir defa 50000 IU D vitamini verilmiş ve inflamatuvar belirteçler üzerindeki etkisi incelenmiştir. Buna göre; 12 hafta sonunda D vitamini alan grupta MCP-1 düzeylerinin anlamlı oranda azaldığı ancak bu düşüşün yılın geri kalanında korunamadığı gösterilmiştir (57). Yapılan diğer bir çalışmada diyaliz tedavisi almayan kronik böbrek hastalarında $25(\mathrm{OH}) \mathrm{D}$ düzeyleri düştükçe hs-CRP ve TNF- $\alpha$ düzeylerinin anlamlı oranda arttı̆̆ gösterilmiştir (58). Hemodiyaliz ve peritoneal diyaliz tedavisi alan ve serum 25(OH)D düzeyleri $20 \mathrm{ng} / \mathrm{mL}$ 'den düşük olan son evre böbrek yetmezliği hastaları ile yapılan bir çalışmada, 12 haftalık (50000 IU, haftada 2 defa) 25(OH)D suplemantasyonu sonucunda serum IL-6 ve CRP düzeylerinde anlamlı bir düşüş olduğu gösterilmiştir (59).

Diğer taraftan kalsitriolün hücre farklılaşmasını engellemeyi, hücre proliferatif aktivitesini inhibe etmeyi ve adaptif immünitenin regülasyonunu inflamatuvar sitokinlerin üretimini azaltarak indüklediği gösterilmiştir. Aynı zamanda, TLR'nin patojenler tarafından monositler/makrofajlar üzerinde stimülasyonu, makrofaj/monositlerde D vitamini reseptörü (VDR) ekspresyonunun artmasına neden olabilmektedir. Böylece, 1,25( $\mathrm{OH})_{2} \mathrm{D}$, katelisidin üretimini artırmaktadır ve bu da makrofaj ve monositlerin etkisini artırabilmektedir (16). Vitamin D3'ün farelerde deneysel olarak oluşturulmuş akut böbrek hasarına etkisinin araştırıldığı bir çalışmada, farelere oral olarak verilen vitamin D3'ün 25(OH)D konsantrasyonunu anlamlı şekilde artırdığı ve renal VDR sinyalizasyonunu anlamlı oranda aktive ettiği belirtilmiştir. Vitamin D3 uygulamasının oksidan ve antioksidan enzimlerin genlerinin regüle ederek tübüler epitel hücre apoptozunu hafiflettiği ve böylece renal oksidatif stresi azaltabildiği de gösterilmiştir (58).

\section{E Vitamini}

E vitamini yağda çözünen bir vitamindir ve insan diyetinde yer alan yağların çoğunda bulunmaktadır. Alfa $(\alpha)$ tokoferol, beta $(\beta)$ tokoferol, gamma $(\gamma)$ tokoferol ve delta $(\delta)$ tokoferol $\mathrm{E}$ vitamininin doymuş formlarıdır bunun yanı sıra, tokotrienoller $(\alpha, \beta, \gamma, \delta)$ doymamış formlardır ve bir isoprenoid yan zincirleri bulunmaktadır. Hem tokoferollerin hem de tokotrienollerin antioksidan ve anti-inflamatuvar etkileri olduğu bilinmektedir (60).
Kronik böbrek hastalarında (son evre hariç) koroner girişim sonrasında gelişebilecek akut böbrek hasarının önlenmesinde $\alpha$-tokoferol ve $\gamma$-tokoferol suplemantasyonunun anlamlı etkisinin olduğu bir çalışmada bildirilmiştir (61). Kronik böbrek hastalığı ve E vitamini ile ilgili yapılan çalışmalar değerlendirildiğinde, genel olarak E vitamini desteği sonrası oksidan stres aracılı inflamatuvar belirteçler ve KVH kaynaklı morbidite ile ilişkili oldukları görülmektedir. Son evre böbrek hastalarında antioksidanlarla kardiyovasküler hastalıkların ikincil korunması çalışmasında (Secondary Prevention with Antioxidants of Cardiovascular Disease in End-Stage Renal Disease (SPACE)), günde 800 IU $\alpha$-tokoferol alan hemodiyaliz hastalarında (var olan kardiyovasküler hastalığ böbrek yetmezliği hastalarında) kontrol grubuna göre miyokard enfarktüs görülme sıklığının anlamlı oranda daha az olduğu rapor edilmiştir (62). Yapılan randomize plasebo kontrollü bir çalışmada, E vitamini (180 mg tokotrienol ve $40 \mathrm{mg}$ tokoferol) suplemantasyonu alan kronik hemodiyaliz hastalarında kontrol grubuna ve başlangıca göre CRP ve IL-6 gibi inflamatuvar parametrelerde anlamlı bir değişiklik gözlenmezken, kan lipid profilinin anlamlı olarak iyileştiği gösterilmiştir (63).

Hemodiyaliz tedavisi alan son evre böbrek yetmezliği hastalarında E vitamini suplemantasyonunun (400 IU $\alpha$-tokoferol/ gün) 2 ay sonunda plazma $\alpha$-tokoferol konsantrasyonunu anlamlı oranda artırdığ 1 buna karşın IL-6, hs-CRP, TNF- $\alpha$ gibi pro-inflamatuvar belirteçlerin düzeyini etkilemediği gösterilmiştir (64). Diğer bir çalışmada 4 ay boyunca $\alpha$-tokoferol suplementasyonu (400 IU) yapilan hemodiyaliz hastalarının (son evre böbrek yetmezliği) inflamatuvar belirteçleri (CRP ve IL-6) daha düşük ve antioksidan kapasiteleri daha yüksek saptanmıştır (65). Gamma tokoferolün son evre böbrek yetmezliği olan ve hemodiyaliz tedavisi alan hastalarda kontrol grubuna göre serum CRP düzeyini anlamlı oranda düşürdüğü de başka bir araştırmada gösterilmiştir (66).

\section{Karnitin}

Karnitin, vücutta enerji üretiminde ve yağ asitleri metabolizmasında hayati rol oynayan ve koşullara bağlı olarak esansiyel olan bir diyet bileşenidir. Karnitin (hidroksi N trimetil aminobütirik asit) hayvansal kaynaklı besinlerin çoğunda bulunmaktadır ancak bitkisel kaynaklı besinlerde sınırlıdır (67). Karnitin ve inflamasyon arasındaki bağlantıya dair mekanizmalar net olmamasına karşın, karnitinin fazla ve toksik olan açil grupların vücuttan uzaklaştırılmasında rol alması ve serbest radikalleri süpürücü etkisinin olmasi; anti-inflamatuvar aktivitesinin altında yatan mekanizmalar olabileceği düşünülmektedir $(68,69)$.

Yapılan bir çalışmaya göre, ratlarda oluşturulan böbrek hasarında, L-karnitin suplementasyonuyla (4 hafta, 50-200 $\mathrm{mg} / \mathrm{kg} /$ gün) transforming büyüme faktörü beta 1 (TGF- $\beta 1$ ) ve 8-hidroksi-2“-deoksiguanozin (8-OHdG) ekspresyonu baskılanarak renal fonksiyon, inflamasyon ve fibroziste iyileşme sağlandığı gösterilmiştir (70). 
Diyaliz tedavisi alan son evre böbrek yetmezliği hastalarında diyaliz sırasında kan karnitin konsantrasyonlarının düştüğü bilinmektedir. Karnitinin $\mathrm{KBH}$ hastalarında pozitif protein dengesine katkı sağlamasının yanı sıra anti-inflamatuvar etkilerinin olabileceği ve organ hasarına karşı koruyucu etkilerinin olduğu sınırlı da olsa bazı çalışmalarda gösterilmiştir (71-73). İntravenöz karnitin suplementasyonunun (20 $\mathrm{mg} / \mathrm{kg}$; haftada 3 defa) son evre böbrek yetmezliği olan hemodiyaliz hastalarında 6 ay sonunda kontrol grubuna göre serum CRP düzeyini anlamlı oranda düşürerek inflamasyonu baskılayabileceği gösterilmiştir (74). Bununla benzer olarak hemodiyaliz hastalarında (son evre böbrek yetmezliği) diyaliz sonrasında karnitin suplemantasyonunun serum CRP ve hs-CRP düzeyini anlamlı oranda düşürdüğünü gösteren çalışmalar da mevcuttur $(75,76)$. Yapılan başka bir çalışmada hemodiyaliz tedavisi alan son evre böbrek yetmezliği hastalarında 12 hafta boyunca günlük $1 \mathrm{~g}$ karnitin suplemantasyonu ile serum karnitin konsantrasyonu başlangıca göre 12. haftanın sonunda anlamlı oranda artarken, serum CRP ve IL-6 düzeyleri anlamlı oranda düşmüştür (77).

\section{Lipoik Asit}

Lipoik asit (LA), veya 1,2-ditiyolan-3-pentanoik asit, mitokondride oktanoik asitten enzimatik olarak sentezlenebilen bir ditiyol bileşiğidir. Lipoik asit, mitokondriyal $\alpha$-ketoasit dehidrogenazlar için gerekli olan bir kofaktördür ve bu nedenle mitokondrial enerji metabolizmasında kritik bir role sahiptir. Vücutta sentezlenmesinin yanı sıra besinlerden de alınabilmektedir ve birçok dokuda geçici olarak birikebilmektedir. Oral olarak alınan LA'nın potansiyel biyolojik antioksidan ve antiinflamatuvar etkilerinin olduğu belirtilmektedir (78). Lipoik asit besinlerde doğal olarak bulunmasına karşın suplementasyonuyla fonksiyonel kapasitesinin daha yüksek olduğu gösterilmiştir. Hem hidrofilik hem de lipofilik ortamda serbest radikallere karş1 etkili olan LA, aynı zamanda $\mathrm{C}$ vitamini, E vitamini ve $\mathrm{GSH}$ (intraselüler indirgenmiş glutatyon) gibi endojen antioksidanlar ile birlikte koordineli olarak çalışarak antioksidan ağda yer almaktadır (79).

Kronik böbrek hastalığında oksidatif stres ve inflamasyon prevalansı çok yüksek olmasına karşın; antioksidan tedavisinin oksidatif stres ve inflamasyon üzerindeki etkileri az çalışılmıştır. Güncel çalışmalar değerlendirildiğinde lipoik asitin etkin olmadığını gösteren insan çalışmaları varken etkin olduğunu gösteren deneysel hayvan çalışmaları literatürde yer almaktadır. Yapılan bir çalışmaya göre, 3. evre $\mathrm{KBH}$ hastalarında 8 hafta boyunca tokoferol (666 IU/gün) ve LA (600 mg/gün) suplementasyonu yapılan grupta kontrol grubuna göre hem oksidatif stres hem de inflamasyon belirteçlerinde anlamlı farklılıklar saptanmamıştır (80). Hemodiyaliz tedavisi alan son evre böbrek yetmezliği hastalarında LA suplementasyonunun (600 mg/gün) inflamasyon, oksidatif stres ve serum lipid profili düzeyleri üzerine etkisinin araştırıldığı randomize kontrollü diğer bir klinik çalışmada da; LA alan grupta hs-
CRP düzeylerinin anlamlı oranda düştügü ancak lipid profili ve oksidatif stres parametreleri açısından gruplar arasında anlamlı bir farklılık olmadığı rapor edilmiştir (81).

Diğer yanda laboratuvar hayvanları üzerinde yapılan çalışmalar, genelde lipoik asitin böbrek hasarı ve inflamasyon üzerine olumlu etkilerini göstermektedir. Tavşanlar üzerinde yapılan bir çalışmada, tavşanlara 3 hafta boyunca 10 veya 50 $\mathrm{mg} / \mathrm{kg} /$ gün LA verilmiştir ve diyabetik nefropati parametreleri üzerindeki etkileri incelenmiştir. Düşük doz (10 mg/kg/gün) LA alımıyla serum üre ve kreatin konsantrasyonları azalmış, diyabet ile indüklenen glutatyon/okside glutatyon oranı (GSH/ GSSG) düşüşü hafifletilmiş ve serum ve böbrek korkteksindeki hidroksil serbest radikallerin birikimi inhibe edilmiştir (82). Yapılan başka bir çalışmada, lipoik asitin NF- $x$ B sinyal yolağ 1 aracılığıyla ratların mesangial hücrelerinde deneysel olarak oluşturulmuş inflamatuvar yanıtı hafifleterek akut böbrek hasarını iyileştirebileceği gösterilmiştir (83). Yine ratlarda deneysel olarak oluşturulan böbrek hasarı ile artan TNF- $\alpha$ düzeylerinin, lipoik asit suplemantasyonu ile düşürüldüğü rapor edilmiştir (84). Başka bir çalışmada ise farelerde deneysel olarak oluşturulan böbrek hasarında, lipoik asit suplemantasyonu ile TNF- $\alpha$ doku düzeylerinin, NF- $\varkappa$ B aktivasyonunun, hücre içi adhezyon molekülü 1 (ICAM-1) ve MCP-1 ekspresyonunun azaldığ 1 ve makrofaj infiltrasyonunun baskılandığ 1 gösterilmiştir (85).

\section{Flavonoidler}

Flavonoidler, geniş polifenol ailesinin bitkilerde en yaygın olan üyesidir. Flavonoidlerin birçok alt sınıfı bulunmaktadır ve bunlar; flavonlar, flavonoller, flavanonlar, isoflavonlar, flavanoller, flavanlar ve antosiyanidinlerdir. Flavonoidlerin bilinen biyolojik aktivitelerinden biri de antioksidan ve antiinflamatuvar aktivite göstermeleridir $(22,86)$.

$\mathrm{Bu}$ konuda yapılan insan çalışmaları hayvan çalışmalarına göre sınırlı sayıda olup olumlu etkiler her bir tür için genelde gösterilmiştir. Hemodiyaliz tedavisi alan ve CRP düzeyi yüksek (>10.0 mg/l) olan son evre böbrek yetmezliği hastalarında 8 hafta boyunca soya isoflavonları suplemantasyonu (diyaliz sonrası soya bazlı içecek (54 mg isoflavon) ve diğer günlerde tahıllı ürün (26 mg isoflavon) veya proteinli bar (26 mg isoflavon)) yapılmıştır. Sekiz haftanın sonunda test grubunda kan isoflavon düzeylerinin kontrol grubuna göre 5-10 kat daha yüksek olduğu ve CRP düzeyinin başlangıca oranla daha düşük olduğu gösterilmiştir (87).

Nar suyunun antioksidan ve anti-inflamatuvar aktivitesinin ellagitanninler, gallotanninler ve elajik asidin yanı sıra, flavonoidlerden antosiyaninler ile de ilişkili olduğu bilinmektedir. Plasebo kontrollü bir çalışmada, son evre böbrek yetmezliği olan hemodiyaliz hastalarına 1 yıl boyunca diyaliz sırasında (haftada $3 \mathrm{kez}) 100 \mathrm{ml}$ nar suyu verilmiştir. Nar suyu tüketiminin protein oksidasyonu, lipid oksidasyonu ve inflamasyon belirteçleri (IL$6, \mathrm{TNF}-\alpha)$ üzerinde anlamlı bir düşüş sağladığı gösterilmiştir. 
Uygulamanın tamamlanmasindan 3 ay sonra test ve plasebo gruplarının oksidatif stres ve inflamasyon parametreleri arasında anlamlı bir farklılık olmadığı saptanmıştır (88). Başka bir çalışmada, flavonoller ve antosiyanidinler açısından zengin olan konsantre kırmızı üzüm suyunun (100 ml/gün) hemodiyaliz tedavisi alan son evre böbrek yetmezliği hastalarında 3. haftanın sonunda serum MCP-1 düzeyini anlamlı olarak düşürdüğü gösterilmiştir (89).

Deneysel hayvan çalışmaları değerlendirildiğinde flavonoid türlerinin etkisinin hem doz hem de kullanılan flavonoid türüne göre farklılık göstermekle birlikte, olumlu etkiye sahip olduğu veya etkilemediği görülmektedir. Yapılan bir çalışmada fruktozla beslenmiş ratların böbreklerinde bir isoflavon olan genistein suplementasyonunun (1mg/kg/gün) inflamasyon, fibrogenezis ve NF- $x$ B aktivasyonunu azalttığ1 görülmüştür. Genistein aynı zamanda bazal membran kalınlığı, podosit sayısında azalma ve glomerüler filtrasyon bariyer integritisi kaybı gibi yapısal değişiklikleri de azaltmıştır (90). Ratlarda yüksek fruktoz tüketimiyle oluşturulmuş renal hasara epikateşinin etkisinin araştırıldığı bir çalışmada; fruktoz tüketimiyle yükselen TNF $\alpha$, indüklenebilir nitrik oksit sentaz (iNOS), ve IL-6 düzeyleri, fruktozla birlikte epikateşin tüketen grupta anlamlı oranda düşmüştür. $\mathrm{Bu}$ nedenle inflamasyonla ilişkili böbrek hasarında epikateşin suplementasyonunun olumlu etkileri olabileceği sonucuna varılmıştır (91).

Bir flavon olan rutinin birçok olumlu sağlık etkisinin olduğu bilinmektedir. Kemirgenlerde kronik böbrek hastalığı ve ilişkili kardiyovasküler hastalıkta rutinin etkisi araştırılmıştır ve rutinin böbrek ve kalp fonksiyonu ile yapısını iyileştirdiği, oksidatif stres belirteçlerinin ekspresyonunu azalttığı gösterilmiştir. Buna karşın rutin, TGF- $\beta$ ve TNF- $\alpha$ gibi inflamatuvar belirteçlerin düzeyini etkilememiştir (92). Bir flavanon olan hesperidinin de böbrek hasarında anti-inflamatuvar özellikleri üzerine çalışılmıştır. Ratlarda deneysel olarak oluşturulan böbrek hasarında, hesperidinin oksidatif stres, inflamasyon (lökosit ve pro-inflamatuvar sitokinlerin infiltrasyonu) ve apoptozisi zayıflatarak böbrek hasarını iyileştirdiği rapor edilmiştir (93).

\section{Probiyotikler ve Prebiyotikler}

Probiyotikler konağa fayda sağlayan canlı mikroorganizmalar olarak tanımlanmaktadır (94). Prebiyotikler ise, insan bağırsak enzimleri ile hidrolize edilemeyen, yararlı bakteriler tarafından seçici olarak fermente edilebilen ve bu seçici fermentasyon sonucunda konağın sağlığında olumlu etkiye neden olan diyet bileşenleri olarak tanımlanmaktadırlar (95). Probiyotikler ve prebiyotiklerin, immün sistemi modifiye ederek inflamasyon üzerine olumlu etkilerinin olduğu bildirilmiştir (96-99).

Kronik böbrek hastalığında bağırsak florası değişmektedir, bu nedenle $\mathrm{KBH}$ hastalarında probiyotik kullanımı gün geçtikçe yaygınlaşmaktadır. Değişen bağırsak florası hastayı birçok yönden etkilemektedir; bunlar arasında gastrointestinal sistem (GIS) sağlığı ve üremik toksinler bulunmaktadır (100). $\mathrm{Bu}$ durum KBH'de bağırsakta pH'nın artmasıla mukozal irritasyon ve yapısal değişiklikler ile sonuçlanmaktadır. Bu fizyolojik değişiklikler de disbiyozis, bakteriyel translokasyon ve endotoksemi ile ilişkilidir ve potansiyel olarak böbrek inflamasyonunu artırabilmektedir $(11,101)$. Üremik toksinlerin, probiyotik suplementasyonu ile düşürülebildiği gösterilmiştir. Ancak kanıta dayalı önerilebilecek özel bir ürün henüz bulunmamaktadır (102). Üre, ürik asit ve oksalatlar gibi pürin metabolizmasının son ürünleri kan dolaşımında yüksek düzeylerde bulunduğunda homeostazın sağlanmasına yardımcı olacak şekilde, kolonda atımlarının sağlanması için bağırsak florası önemlidir (11).

Gastrointestinal disbiyozis aracılı bakteri yükü ve endotoksinlerin, renal inflamasyonla ilişkili olduğu ve kronik böbrek hastalığı gelişimine neden olabileceği daha çok gündeme gelen bir konu olmaktadır. Bu nedenle bağırsakla böbrekler arasında bir bağlantı olduğu düşünülmektedir. Bağırsaklarda anaerobik bakteri fermentasyonunun ana metabolik ürünü olan kısa zincirli yă asitlerinin intestinal fonksiyon ile ilişkili potansiyel medyatörler olup, kan dolaşımı ile inflamatuvar gen ekspresyonu, kemotaksis, diferansiyon, proliferasyon ve apoptozis aracılığıyla immün sistem ve mikrobiyota arasındaki bağlantıyı oluşturduğu düşünülmektedir $(103,104)$. Kronik böbrek hastalığında disbiyosis giderek potansiyel bir tedavi hedefi olarak kabul ediliyor olmasına karşın bilimsel veriler henüz yeterli değildir (14).

Kronik böbrek hastalığı olan bireylerde, ileri renal yetmezlik, nitrojen bileşiklerinin (üre ve ürik asit) serum düzeylerinin artışıyla sonuçlanan, glomerüler filtrasyon ve tübüler sekresyonu kötüleştirmektedir. Bu nitrojen bileşikleri bağırsaklara ulaşabilmekte ve fermentasyonla üremik toksinlerin üretimini sağlayan bakteri türlerinin aşırı çoğalmasına neden olabilmektedir ve bu bakteriler Laktobasiller gibi gibi koruyucu türde bakterilere göre daha baskın hale gelebilmektedirler (11). Böbrek hasarının insanlarda bağırsak mikrobiyotasının bileşimini modifiye edebileceği gösterilmiştir. Yapılan bir çalışmada, son evre böbrek hastalarında özellikle psödomonas ailesine ait bakteriyel operasyonel taksonomik ünitelerde anlamlı bir artış olurken, sağlıklı bireylerde bakteriyel operasyonel taksonomik ünitelerde daha çok sutterellas, bakteroidesea ve laktobasillosea ailelerinde yoğunlaşmıştır (105). Peritoneal diyaliz tedavisi alan son evre böbrek yetmezliği hastalarında probiyotik suplemantasyonunun (6 ay boyunca her gün; $10^{9}$ koloni oluşturan birim (kob) bifidobakterium bifidum, $10^{9} \mathrm{kob}$ bifidobakterium catenulatum, $10^{9}$ kob bifidobakterium longum ve $10^{9}$ kob laktobasillus plantarum içeren kapsül) serum endoksin ve pro-inflamatuvar sitokinlerin (TNF- $\alpha$ ve IL-6) düzeyini düşürdüğü gösterilmiştir. Bunun yanı sıra suplemantasyon ile anti-inflamatuvar sitokinlerin (IL-10) serum düzeyinde anlamlı oranda artış gözlenmiştir (106). 
Kronik böbrek hastalığında hiperkalemiyi önlemek amacıyla genellikle meyve ve sebzelerden kısıtlı diyetler önerilmektedir. $\mathrm{Bu}$ durum diyetin prebiyotik içeriğinin kısıtlı olmasına ve disbiyozise neden olabilmektedir. Ratlarda yüksek dirençli nişastanın oksidatif stres ve inflamasyonu hafifleterek $\mathrm{KBH}$ gelişimini yavaşlattığı gösterilmiştir (107). Kronik böbrek hastalarında (3. evre veya daha ileri evre), posa tüketiminin inflamasyon ile ilişkisini değerlendiren ve NHANES III verilerini içeren bir çalışmada; $\mathrm{KBH}$ hastalarında toplam posa tüketiminde her $10 \mathrm{~g} /$ gün artışla CRP düzeyinin odds oranının \%38 oranında düştüğü gösterilmiştir (108).

\section{SONUÇ ve ÖNERILLER}

Sonuç olarak, her geçen gün insidansı artan bir sağlık sorunu olan KBH'de, inflamasyon hem hastalık nedeni olabilmekte, hem de hastalığın progresyonu sonucunda oluşarak vücutta organ dejenerasyonlarına neden olabilmektedir. Hem hastalığın ilerlemesini yavaşlatmak hem de hastalığa bağlı mortaliteyi azaltmak amacıyla inflamasyonu kontrol altına almak oldukça önemlidir. Beslenme, kronik inflamasyonun oluşumu ve kontrol altına alınmasında önemli bir düzenleyicidir. Güncel literatürde çoklu doymamış yă̆ asitleri, D vitamini, E vitamini, karnitin, lipoik asit, flavanoidler, probiyotikler ve prebiyotiklerin kontrollü insan çalışmaları ve deneysel hayvan çalışmalarında kronik inflamatuvar yanıtı azaltabildiğine dair kanıtlar yer almaktadır. Diyet bileşenleri ve inflamasyon ile ilgili yapılan bu çalışmalar kesitsel veya retrospektif olup genelde son evre böbrek yetmezliği ve diyaliz alma durumuna göre irdelenmiştir. Ancak kronik böbrek hastalığının evresi, eşlik eden hastalıklar ve patofizyolojik süreç ile ilaç tedavisi göz önünde bulundurularak beslenme desteği ve diyet önerilerinin geliştirilmesi gerekmektedir. Ayrıca beslenme açısından öneriler verilebilmesi için, bu sonuçlar daha fazla araştırma ile desteklenmelidir.

\section{KAYNAKLAR}

1. Hill NR, Fatoba ST, Oke JL, Hirst JA, O'Callaghan CA, Lasserson DS, Hobbs FDR: Global prevalence of chronic kidney disease - A systematic review and meta-analysis. PLoS ONE 2016;11:e0158765

2. Suleymanlar G, Utas C, Arinsoy T, Ates K, Altun B, Altiparmak MR, Ecder T, Yilmaz ME, Camsari T, Basci A, Odabas AR, Serdengecti K: A population-based survey of Chronic Renal Disease In Turkey-the CREDIT study. Nephrol Dial Transplant 2011;26:1862-1871

3. Neugarten J, Reckelhoff JF: Gender issues in chronic kidney disease. In: Chronic Renal Disease. San Diego: Academic Press, 2015;69-80

4. Remuzzi G, Benigni A, Finkelstein FO, Grunfeld JP, Joly D, Katz I, Liu ZH, Miyata T, Perico N, Rodriguez-Iturbe B, Antiga L, Schaefer F, Schieppati A, Schrier RW, Tonelli M: Kidney failure: Aims for the next 10 years and barriers to success. Lancet 2013;382:353-362
5. Lozano R, Naghavi M, Foreman K, Lim S, Shibuya K, Aboyans V, Abraham J, Adair T, Aggarwal R, Ahn SY, Alvarado M, Anderson HR, Anderson LM, Andrews KG, Atkinson C, Baddour LM, Barker-Collo S, Bartels DH, Bell ML, Benjamin EJ, Bennett D, Bhalla K, Bikbov B, Bin Abdulhak A, Birbeck G, Blyth F, Bolliger I, Boufous S, Bucello C, Burch M, Burney P, Carapetis J, Chen H, Chou D, Chugh SS, Coffeng LE, Colan SD, Colquhoun $\mathrm{S}$, Colson KE, Condon J, Connor MD, Cooper LT, Corriere M, Cortinovis M, de Vaccaro KC, Couser W, Cowie BC, Criqui MH, Cross M, Dabhadkar KC, Dahodwala N, De Leo D, Degenhardt L, Delossantos A, Denenberg J, Des Jarlais DC, Dharmaratne SD, Dorsey ER, Driscoll T, Duber H, Ebel B, Erwin PJ, Espindola P, Ezzati M, Feigin V, Flaxman AD, Forouzanfar MH, Fowkes FG, Franklin R, Fransen M, Freeman MK, Gabriel SE, Gakidou E, Gaspari F, Gillum RF, Gonzalez-Medina D, Halasa YA, Haring D, Harrison JE, Havmoeller R, Hay RJ, Hoen B, Hotez PJ, Hoy D, Jacobsen KH, James SL, Jasrasaria R, Jayaraman S, Johns N, Karthikeyan G, Kassebaum N, Keren A, Khoo JP, Knowlton LM, Kobusingye O, Koranteng A, Krishnamurthi R, Lipnick M, Lipshultz SE, Ohno SL, Mabweijano J, MacIntyre MF, Mallinger L, March L, Marks GB, Marks R, Matsumori A, Matzopoulos R, Mayosi BM, McAnulty JH, McDermott MM, McGrath J, Mensah GA, Merriman TR, Michaud C, Miller M, Miller TR, Mock C, Mocumbi AO, Mokdad AA, Moran A, Mulholland K, Nair MN, Naldi L, Narayan KM, Nasseri K, Norman P, O’Donnell M, Omer SB, Ortblad K, Osborne R, Ozgediz D, Pahari B, Pandian JD, Rivero AP, Padilla RP, Perez-Ruiz F, Perico N, Phillips D, Pierce K, Pope CA, 3rd, Porrini E, Pourmalek F, Raju M, Ranganathan D, Rehm JT, Rein DB, Remuzzi G, Rivara FP, Roberts T, De Leon FR, Rosenfeld LC, Rushton L, Sacco RL, Salomon JA, Sampson U, Sanman E, Schwebel DC, Segui-Gomez M, Shepard DS, Singh D, Singleton J, Sliwa K, Smith E, Steer A, Taylor JA, Thomas B, Tleyjeh IM, Towbin JA, Truelsen T, Undurraga EA, Venketasubramanian N, Vijayakumar L, Vos T, Wagner GR, Wang M, Wang W, Watt K, Weinstock MA, Weintraub R, Wilkinson JD, Woolf AD, Wulf S, Yeh PH, Yip P, Zabetian A, Zheng ZJ, Lopez AD, Murray CJ, AlMazroa MA, Memish ZA: Global and regional mortality from 235 causes of death for 20 age groups in 1990 and 2010: A systematic analysis for the Global Burden of Disease Study 2010. Lancet 2012;380:2095-2128

6. Sampaio-Maia B, Simões-Silva L, Pestana M, Araujo R, SoaresSilva IJ: The role of the gut microbiome on chronic kidney disease. In: Sima S, Geoffrey Michael G (eds), Advances in Applied Microbiology. London: Academic Press, 2016;65-94

7. Eleftheriadis T, Antoniadi G, Liakopoulos V, Kartsios C, Stefanidis I: Disturbances of acquired immunity in hemodialysis patients. Semin Dial 2007;20:440-451

8. Hung KC, Wu CC, Chen HS, Ma WY, Tseng CF, Yang LK, Hsieh HL, Lu KC: Serum IL-6, albumin and co-morbidities are closely correlated with symptoms of depression in patients on maintenance haemodialysis. Nephrol Dial Transplant 2011;26:658-664

9. Munoz Mendoza J, Isakova T, Cai X, Bayes LY, Faul C, Scialla JJ, Lash JP, Chen J, He J, Navaneethan S, Negrea L, Rosas SE, Kretzler M, Nessel L, Xie D, Anderson AH, Raj DS, Wolf M, Appel LJ, Feldman HI, Go AS, He J, Kusek JW, Lash JP, Ojo A, Townsend RR: Inflammation and elevated levels of fibroblast growth factor 23 are independent risk factors for death in chronic kidney disease. Kidney Int 2017;91:711-719 
10. Kumar V, Abbas AK, Aster JC: Robbins Basic Pathology (9nd ed). Philadelphia: Elsevier Health Sciences,2013;472-489

11. Felizardo RJF, Castoldi A, Andrade-Oliveira V, Camara NOS: The microbiota and chronic kidney diseases: A double-edged sword. Clin Trans Immunol 2016;5:e86

12. National Kidney Foundation: Clinical practice guidelines for chronic kidney disease: Evaluation, classification and stratification. National Kidney Foundation [İnternet yayını]. 2002 [atıf 20.01.2017]. Erişim: https://www.kidney.org/sites/default/ files/docs/ckd_evaluation_classification_stratification.pdf

13. Abboud O, Adler S, Bertram K, Garabed E, Norbert L, Wheeler D: Clinical Practice Guideline for the Evaluation and Management of Chronic Kidney Disease. KDİGO [İnternet Yayını]. 2012 [atıf 12.07.2017]; 3: 5-127. Erişim: http://www.kdigo.org/clinical_ practice_guidelines/pdf/CKD/KDIGO_2012_CKD_GL.pdf

14. Nallu A, Sharma S, Ramezani A, Muralidharan J, Raj D: Gut microbiome in chronic kidney disease: Challenges and opportunities. Transl Res 2016;179:24-37

15. Evans PD, Taal MW: Epidemiology and causes of chronic kidney disease. Medicine 2015;39:402-406

16. Liu WC, Zheng CM, Lu CL, Lin YF, Shyu JF, Wu CC, Lu KC: Vitamin D and immune function in chronic kidney disease. Clin Chim Acta 2015;450:135-144

17. Eustace JA, Astor B, Muntner PM, Ikizler TA, Coresh J: Prevalence of acidosis and inflammation and their association with low serum albumin in chronic kidney disease. Kidney Int 2004;65:1031-1040

18. Carrero JJ, Stenvinkel P: Inflammation in Chronic Kidney Disease A2 - Kopple, Joel D. In: Massry SG, Kalantar-Zadeh K (eds), Nutritional Management of Renal Disease. (3rd ed). London: Academic Press, 2013;79-91

19. Shankar A, Sun L, Klein BE, Lee KE, Muntner P, Nieto FJ, Tsai MY, Cruickshanks KJ, Schubert CR, Brazy PC, Coresh J, Klein R: Markers of inflammation predict the long-term risk of developing chronic kidney disease: A population-based cohort study. Kidney Int 2011;80:1231-1238

20. Silverstein DM: Inflammation in chronic kidney disease: Role in the progression of renal and cardiovascular disease. Pediatr Nephrol 2009;24:1445-1452

21. Sreedhar R, Watanabe K, Arumugam S: General Mechanisms of Immunity and Inflammation. In: Japanese Kampo Medicines for the Treatment of Common Diseases: Focus on Inflammation. Academic Press, 2017; 23-31

22. Neff K, Le Roux C: Chronic kidney disease and inflammation. In: Immunonutrition. New York: CRC Press 2014; 167-180

23. Franceschi C, Campisi J: Chronic Inflammation (Inflammaging) and its potential contribution to age-associated diseases. J Gerontol A Biol Sci Med Sci 2014;69:4-9

24. Levy BD, Serhan CN: Resolution and regulation of inflammation. In: Mitchell RN (ed), Pathobiology of Human Disease. San Diego: Academic Press, 2014;332-348
25. Fleit HB: Chronic Inflammation. In: Mitchell RN (ed), Pathobiology of Human Disease. San Diego: Academic Press, 2014; 300-314

26. Kovesdy CP, Kalantar-Zadeh K: Inflammation in chronic kidney disease. In: Sayegh MH (ed), Chronic Kidney Disease, Dialysis, and Transplantation. (3rd ed). Philadelphia: WB Saunders, 2010; 183-197

27. Pahl MV, Vaziri ND: Immune function in chronic kidney disease. In: Chronic Renal Disease. San Diego: Academic Press, 2015; 285-297

28. Oberg BP, McMenamin E, Lucas FL, McMonagle E, Morrow J, Ikizler TA, Himmelfarb J: Increased prevalence of oxidant stress and inflammation in patients with moderate to severe chronic kidney disease. Kidney Int 2004;65:1009-1016

29. Carrero JJ, Yilmaz MI, Lindholm B, Stenvinkel P: Cytokine dysregulation in chronic kidney disease: How can we treat it? Blood Purif 2008;26:291-299

30. Shlipak MG, Fried LF, Crump C, Bleyer AJ, Manolio TA, Tracy RP, Furberg CD, Psaty BM: Elevations of inflammatory and procoagulant biomarkers in elderly persons with renal insufficiency. Circulation 2003;107:87-92

31. Keller C, Katz R, Cushman M, Fried LF, Shlipak M: Association of kidney function with inflammatory and procoagulant markers in a diverse cohort: A cross-sectional analysis from the MultiEthnic Study of Atherosclerosis (MESA). BMC Nephrol 2008;9:9

32. Upadhyay A, Larson MG, Guo CY, Vasan RS, Lipinska I, O’Donnell CJ, Kathiresan S, Meigs JB, Keaney JF Jr, Rong J, Benjamin EJ, Fox CS: Inflammation, kidney function and albuminuria in the Framingham Offspring cohort. Nephrol Dial Transplant 2011;26:920-926

33. Gupta J, Mitra N, Kanetsky PA, Devaney J, Wing MR, Reilly M, Shah VO, Balakrishnan VS, Guzman NJ, Girndt M, Periera BG, Feldman HI, Kusek JW, Joffe MM, Raj DS: Association between albuminuria, kidney function, and inflammatory biomarker profile in CKD in CRIC. Clin J Am Soc Nephrol 2012;7:1938-1946

34. Bazeley J, Bieber B, Li Y, Morgenstern H, de Sequera P, Combe C, Yamamoto H, Gallagher M, Port FK, Robinson BM: $\mathrm{C}$-reactive protein and prediction of 1-year mortality in prevalent hemodialysis patients. Clin J Am Soc Nephrol 2011;6:2452-2461

35. Honda H, Qureshi AR, Heimburger O, Barany P, Wang K, PecoitsFilho R, Stenvinkel P, Lindholm B: Serum albumin, C-reactive protein, interleukin 6 , and fetuin a as predictors of malnutrition, cardiovascular disease, and mortality in patients with ESRD. Am J Kidney Dis 2006;47:139-148

36. Shivappa N, Hebert JR, Rietzschel ER, De Buyzere ML, Langlois M, Debruyne E, Marcos A, Huybrechts I: Associations between dietary inflammatory index and inflammatory markers in the Asklepios Study. Br J Nutr 2015;113:665-671

37. Cavicchia PP, Steck SE, Hurley TG, Hussey JR, Ma Y, Ockene IS, Hebert JR: A new dietary inflammatory index predicts interval changes in serum high-sensitivity C-reactive protein. J Nutr 2009;139:2365-2372 
38. Leavy O: Immune regulation: Brain-fat axis in adaptive immunity. Nat Rev Immunol 2015;15:267

39. Kim MS, Yan J, Wu W, Zhang G, Zhang Y, Cai D: Rapid linkage of innate immunological signals to adaptive immunity by the brain-fat axis. Nat Immunol 2015;16:525-533

40. Harbige LS: Dietary n-6 and n-3 fatty acids in immunity and autoimmune disease. Proc Nutr Soc 1998;57:555-562

41. Calder PC, Grimble RF: Polyunsaturated fatty acids, inflammation and immunity. Eur J Clin Nutr 2002;56:14-19

42. Calder PC: n-3 Polyunsaturated fatty acids, inflammation, and inflammatory diseases. Am J Clin Nutr 2006;83:1505-1519

43. Gopinath B, Harris DC, Flood VM, Burlutsky G, Mitchell P: Consumption of long-chain n-3 PUFA, alpha-linolenic acid and fish is associated with the prevalence of chronic kidney disease. Br J Nutr 2011;105:1361-1368

44. Lauretani F, Semba RD, Bandinelli S, Miller ER, Ruggiero C, Cherubini A, Guralnik JM, Ferrucci L: Plasma polyunsaturated fatty acids and the decline of renal function. Clin Chem 2008;54:475-481

45. Priante $\mathrm{G}$, Musacchio E, Valvason C, Baggio B: EPA and DHA suppress AngII- and arachidonic acid-induced expression of profibrotic genes in human mesangial cells. J Nephrol 2009;22:137-143

46. Priante G, Musacchio E, Valvason C, Clari G, Bordin L, Sartori L, Baggio B: Further insights about the beneficial effects of $n-3$ fatty acids in the early molecular events of renal fibrosis in vitro. J Nephrol 2013;26:652-659

47. Rasic-Milutinovic Z, Perunicic G, Pljesa S, Gluvic Z, Sobajic S, Djuric I, Ristic D: Effects of N-3 PUFAs supplementation on insulin resistance and inflammatory biomarkers in hemodialysis patients. Ren Fail 2007;29:321-329

48. Sabbatini M, Apicella L, Cataldi M, Maresca I, Nastasi A, Vitale S, Memoli B, Postiglione L, Riccio E, Gallo R, Federico S, Guida B: Effects of a diet rich in N-3 polyunsaturated fatty acids on systemic inflammation in renal transplant recipients. J Am Coll Nutr 2013;32:375-383

49. Peake JM, Gobe GC, Fassett RG, Coombes JS: The effects of dietary fish oil on inflammation, fibrosis and oxidative stress associated with obstructive renal injury in rats. Mol Nutr Food Res 2011;55:400-410

50. Perunicic-Pekovic GB, Rasic ZR, Pljesa SI, Sobajic SS, Djuricic I, Maletic R, Ristic-Medic DK: Effect of n-3 fatty acids on nutritional status and inflammatory markers in haemodialysis patients. Nephrology (Carlton) 2007;12:331-336

51. Naini AE, Asiabi RE, Keivandarian N, Moeinzadeh F: Effect of omega-3 supplementation on inflammatory parameters in patients on chronic ambulatory peritoneal dialysis. Adv Biomed Res 2015;4:167-174

52. Li H, Ruan XZ, Powis SH, Fernando R, Mon WY, Wheeler DC, Moorhead JF, Varghese Z: EPA and DHA reduce LPS-induced inflammation responses in HK-2 cells: Evidence for a PPARgamma-dependent mechanism. Kidney Int 2005;67:867-874
53. Santoro D, Caccamo D, Gagliostro G, Ientile R, Benvenga S, Bellinghieri G, Savica V: Vitamin D metabolism and activity as well as genetic variants of the vitamin D receptor (VDR) in chronic kidney disease patients. J Nephrol 2013;26:636-644

54. Wolf M, Shah A, Gutierrez O, Ankers E, Monroy M, Tamez H, Steele D, Chang Y, Camargo CA, Tonelli M, Thadhani R: Vitamin D levels and early mortality among incident hemodialysis patients. Kidney Int 2007;72:1004-1013

55. Bakdash G, van Capel TMM, Mason LMK, Kapsenberg ML, de Jong EC: Vitamin D3 metabolite calcidiol primes human dendritic cells to promote the development of immunomodulatory IL-10producing T cells. Vaccine 2014;32:6294-6302

56. Yadav AK, Banerjee D, Lal A, Jha V: Vitamin D deficiency, CD4+CD28null cells and accelerated atherosclerosis in chronic kidney disease. Nephrology (Carlton) 2012;17:575-581

57. Alvarez JA, Zughaier SM, Law J, Hao L, Wasse H, Ziegler TR, Tangpricha V: Effects of high-dose cholecalciferol on serum markers of inflammation and immunity in patients with early chronic kidney disease. Eur J Clin Nutr 2013;67:264-269

58. Xu S, Chen YH, Tan ZX, Xie DD, Zhang C, Xia MZ, Wang H, Zhao H, Xu DX, Yu DX: Vitamin D3 pretreatment alleviates renal oxidative stress in lipopolysaccharide-induced acute kidney injury. J Steroid Biochem Mol Biol 2015;152:133-141

59. Meireles MS, Kamimura MA, Dalboni MA, Giffoni de Carvalho JT, Aoike DT, Cuppari L: Effect of cholecalciferol on vitamin D-regulatory proteins in monocytes and on inflammatory markers in dialysis patients: A randomized controlled trial. Clinical Nutrition 2016;35:1251-1258

60. Aggarwal BB, Sundaram C, Prasad S, Kannappan R: Tocotrienols, the vitamin $\mathrm{E}$ of the 21 st century: Its potential against cancer and other chronic diseases. Biochem Pharmacol 2010;80:1613-1631

61. Tasanarong A, Vohakiat A, Hutayanon P, Piyayotai D: New strategy of alpha- and gamma-tocopherol to prevent contrastinduced acute kidney injury in chronic kidney disease patients undergoing elective coronary procedures. Nephrol Dial Transplant 2013;28:337-344

62. Boaz M, Smetana S, Weinstein T, Matas Z, Gafter U, Iaina A, Knecht A, Weissgarten Y, Brunner D, Fainaru M, Green MS: Secondary prevention with antioxidants of cardiovascular disease in endstage renal disease (SPACE): Randomised placebocontrolled trial. Lancet 2000;356:1213-1218

63. Daud ZA, Tubie B, Sheyman M, Osia R, Adams J, Tubie S, Khosla P: Vitamin E tocotrienol supplementation improves lipid profiles in chronic hemodialysis patients. Vasc Health Risk Manag 2013;9:747-761

64. Smith KS, Lee CL, Ridlington JW, Leonard SW, Devaraj S, Traber MG: Vitamin E supplementation increases circulating vitamin $\mathrm{E}$ metabolites tenfold in end-stage renal disease patients. Lipids 2003;38:813-819

65. Maniglia FP, Alberto dos Santos RM, Cardeal da Costa JA: The role of nutrition and supplementation in dialysis patient health. In: Dokken BB (ed), Glucose Intake and Utilization in Pre-Diabetes and Diabetes. Boston: Academic Press, 2015;341-347 
66. Himmelfarb J, Kane J, McMonagle E, Zaltas E, Bobzin S, Boddupalli S, Phinney S, Miller G: Alpha and gamma tocopherol metabolism in healthy subjects and patients with end-stage renal disease. Kidney Int 2003;64:978-991

67. Salama AF, Kasem SM, Tousson E, Elsisy MKH: Protective role of L-carnitine and vitamin $\mathrm{E}$ on the kidney of atherosclerotic rats. Biomedicine \& Aging Pathology 2012;2:212-215

68. Lee B-J, Lin J-S, Lin Y-C, Lin P-T: Antiinflammatory effects of 1-carnitine supplementation $(1000 \mathrm{mg} / \mathrm{d})$ in coronary artery disease patients. Nutrition 2015;31:475-479

69. Khalatbari-Soltani S, Tabibi H: Inflammation and 1-carnitine therapy in hemodialysis patients: A review. Clin Exp Nephrol 2015;19:331-335

70. Xiang Y, Piao SG, Zou HB, Jin J, Fang MR, Lei DM, Gao BH, Yang CW, Li C: L-Carnitine protects against cyclosporineinduced pancreatic and renal injury in rats. Transplant Proc 2013;45:3127-3134

71. Bellinghieri G, Santoro D, Calvani M, Savica V: Role of carnitine in modulating acute-phase protein synthesis in hemodialysis patients. J Ren Nutr 2005;15:13-17

72. Chen Y, Abbate M, Tang L, Cai G, Gong Z, Wei R, Zhou J, Chen $\mathrm{X}$ : L-Carnitine supplementation for adults with end-stage kidney disease requiring maintenance hemodialysis: A systematic review and meta-analysis. Am J Clin Nutr 2014;99:408-422

73. Zambrano S, Blanca AJ, Ruiz-Armenta MV, Miguel-Carrasco JL, Arévalo M, Mate A, Vázquez CM: L-Carnitine attenuates the development of kidney fibrosis in hypertensive rats by upregulating PPAR- $\gamma$. Am J Hypertens 2014;27:460-470

74. Savica V, Santoro D, Mazzaglia G, Ciolino F, Monardo P, Calvani M, Bellinghieri G, Kopple JD: L-carnitine infusions may suppress serum C-reactive protein and improve nutritional status in maintenance hemodialysis patients J Ren Nutr 2005;15:225230

75. Duranay M, Akay H, Yilmaz FM, Senes M, Tekeli N, Yucel D: Effects of L-carnitine infusions on inflammatory and nutritional markers in haemodialysis patients. Nephrol Dial Transplant 2006;21:3211-3214

76. Suchitra MM, Ashalatha VL, Sailaja E, Rao AM, Reddy VS, Bitla AR, Sivakumar V, Rao PV: The effect of L-carnitine supplementation on lipid parameters, inflammatory and nutritional markers in maintenance hemodialysis patients. Saudi J Kidney Dis Transpl 2011;22:1155-1159

77. Shakeri A, Tabibi H, Hedayati M: Effects of L-carnitine supplement on serum inflammatory cytokines, C-reactive protein, lipoprotein (a), and oxidative stress in hemodialysis patients with Lp (a) hyperlipoproteinemia. Hemodial Int 2010;14:498-504

78. Shay KP, Moreau RF, Smith EJ, Smith AR, Hagen TM: Alphalipoic acid as a dietary supplement: Molecular mechanisms and therapeutic potential. Biochim Biophys Acta 2009;1790:11491160

79. Abdel-Zaher AO, Abdel-Hady RH, Mahmoud MM, Farrag MMY: The potential protective role of alpha-lipoic acid against acetaminophen-induced hepatic and renal damage. Toxicology 2008;243:261-270
80. Ramos LF, Kane J, McMonagle E, Le P, Wu P, Shintani A, Ikizler TA, Himmelfarb J: Effects of combination tocopherols and alpha lipoic acid therapy on oxidative stress and inflammatory biomarkers in chronic kidney disease. J Ren Nutr 2011;21:211218

81. Khabbazi T, Mahdavi R, Safa J, Pour-Abdollahi P: Effects of alpha-lipoic acid supplementation on inflammation, oxidative stress, and serum lipid profile levels in patients with end-stage renal disease on hemodialysis. J Ren Nutr 2012;22:244-250

82. Winiarska K, Malinska D, Szymanski K, Dudziak M, Bryla J: Lipoic acid ameliorates oxidative stress and renal injury in alloxan diabetic rabbits. Biochimie 2008;90:450-459

83. Lee KA, Lee YJ, Ban JO, Lee YJ, Lee SH, Cho MK, Nam HS, Hong JT, Shim JH: The flavonoid resveratrol suppresses growth of human malignant pleural mesothelioma cells through direct inhibition of specificity protein 1. Int J Mol Med 2012;30:21-27

84. Bae EH, Lee J, Ma SK, Kim IJ, Frokiaer J, Nielsen S, Kim SY, Kim SW: Alpha-Lipoic acid prevents cisplatin-induced acute kidney injury in rats. Nephrol Dial Transplant 2009;24:26922700

85. Kang KP, Kim DH, Jung YJ, Lee AS, Lee S, Lee SY, Jang KY, Sung MJ, Park SK, Kim W: Alpha-lipoic acid attenuates cisplatin-induced acute kidney injury in mice by suppressing renal inflammation. Nephrol Dial Transplant 2009;24:3012-3020

86. Zhang H, Tsao R: Dietary polyphenols, oxidative stress and antioxidant and anti-inflammatory effects. Current Opinion in Food Science 2016;8:33-42

87. Fanti P, Asmis R, Stephenson TJ, Sawaya BP, Franke AA: Positive effect of dietary soy in ESRD patients with systemic inflammation-correlation between blood levels of the soy isoflavones and the acute-phase reactants. Nephrol Dial Transplant 2006;21:2239 2246

88. Shema-Didi L, Sela S, Ore L, Shapiro G, Geron R, Moshe G, Kristal B: One year of pomegranate juice intake decreases oxidative stress, inflammation, and incidence of infections in hemodialysis patients: A randomized placebo-controlled trial. Free Radic Biol Med 2012;53:297-304

89. Castilla P, Echarri R, Davalos A, Cerrato F, Ortega H, Teruel JL, Lucas MF, Gomez-Coronado D, Ortuno J, Lasuncion MA: Concentrated red grape juice exerts antioxidant, hypolipidemic, and antiinflammatory effects in both hemodialysis patients and healthy subjects. Am J Clin Nutr 2006;84:252-262

90. Palanisamy N, Kannappan S, Anuradha CV: Genistein modulates NF- $x$ B-associated renal inflammation, fibrosis and podocyte abnormalities in fructose-fed rats. Eur J Pharmacol 2011;667:355364

91. Prince PD, Lanzi CR, Toblli JE, Elesgaray R, Oteiza PI, Fraga CG, Galleano M: Dietary (-)-epicatechin mitigates oxidative stress, NO metabolism alterations, and inflammation in renal cortex from fructose-fed rats. Free Radic Biol Med 2016;90:35-46

92. Diwan V, Brown L, Gobe GC: The flavonoid rutin improves kidney and heart structure and function in an adenine-induced rat model of chronic kidney disease. Journal of Functional Foods 2017;33:85-93 
93. Sahu BD, Kuncha M, Sindhura GJ, Sistla R: Hesperidin attenuates cisplatin-induced acute renal injury by decreasing oxidative stress, inflammation and DNA damage. Phytomedicine 2013;20: 453-460

94. FAO/WHO Working Group: Guidelines for the Evaluation of Probiotics in Food. FAO/WHO [İnternet yayın1]. 2002 [atıf 22.02.2017]. Erişim: http://www.who.int/foodsafety/fs_ management/en/probiotic_guidelines.pdf

95. Gibson GR: Fibre and effects on probiotics (the prebiotic concept). Clinical Nutrition Supplements 2004;1:25-31

96. Maslowski KM, Mackay CR: Diet, gut microbiota and immune responses. Nat Immunol 2011;12:5-9

97. Frei R, Akdis M, O’Mahony L: Prebiotics, probiotics, synbiotics, and the immune system: Experimental data and clinical evidence. Curr Opin Gastroenterol 2015;31:153-158

98. Purchiaroni F, Tortora A, Gabrielli M, Bertucci F, Gigante G, Ianiro G, Ojetti V, Scarpellini E, Gasbarrini A: The role of intestinal microbiota and the immune system. Eur Rev Med Pharmacol Sci 2013;17:323-333

99. Fernández J, Redondo-Blanco S, Gutiérrez-del-Río I, Miguélez EM, Villar CJ, Lombó F: Colon microbiota fermentation of dietary prebiotics towards short-chain fatty acids and their roles as anti-inflammatory and antitumour agents: A review. Journal of Functional Foods 2016;25:511-522

100. Zirker L: Probiotic use in chronic kidney disease patients. J Ren Nutr 2014;24:47-49

101. Hatch M, Vaziri ND: Enhanced enteric excretion of urate in rats with chronic renal failure. Clin Sci (Lond) 1994;86:511-516
102. Rossi M, Klein K, Johnson DW, Campbell KL: Pre-,pro-, and synbiotics: Do they have a role in reducing uremic toxins? A systematic review and meta-analysis. Int J Nephrol 2012;2012:673631

103. Huang W, Zhou L, Guo H, Xu Y, Xu Y: The role of short-chain fatty acids in kidney injury induced by gut-derived inflammatory response. Metabolism 2017;68:20-30

104. Smith PM, Howitt MR, Panikov N, Michaud M, Gallini CA, Bohlooly YM, Glickman JN, Garrett WS: The microbial metabolites, short-chain fatty acids, regulate colonic Treg cell homeostasis. Science 2013;341:569-573

105. Vaziri ND, Wong J, Pahl M, Piceno YM, Yuan J, DeSantis TZ, Ni Z, Nguyen TH, Andersen GL: Chronic kidney disease alters intestinal microbial flora. Kidney Int 2013;83:308-315

106. Wang IK, Wu YY, Yang YF, Ting IW, Lin CC, Yen TH, Chen $\mathrm{JH}$, Wang $\mathrm{CH}$, Huang $\mathrm{CC}$, Lin $\mathrm{HC}$ : The effect of probiotics on serum levels of cytokine and endotoxin in peritoneal dialysis patients: A randomised, double-blind, placebo-controlled trial. Benef Microbes 2015;6:423-430

107. Vaziri ND, Liu S-M, Lau WL, Khazaeli M, Nazertehrani S, Farzaneh SH, Kieffer DA, Adams SH, Martin RJ: High amylose resistant starch diet ameliorates oxidative stress, inflammation, and progression of chronic kidney disease. PLoS ONE 2014;9: 114881

108. Krishnamurthy VM, Wei G, Baird BC, Murtaugh M, Chonchol MB, Raphael KL, Greene T, Beddhu S: High dietary fiber intake is associated with decreased inflammation and all-cause mortality in patients with chronic kidney disease. Kidney Int 2012;81:300306 